\title{
Teucrium polium plant extract provokes significant cell death in human lung cancer cells
}

\author{
Khadidja Haïdara $^{1}$, Amal Alachkar ${ }^{2,3}$, Ala-Eddin Al Moustafa ${ }^{1,3,4,5^{*}}$ \\ ${ }^{1}$ Segal Cancer Centre, Lady Davis Institute for Medical Research, McGill University, Montreal, Canada; ${ }^{*}$ Corresponding Author: \\ ala-eddin.almoustafa@mcgill.ca \\ ${ }^{2}$ Faculty of Pharmacy/University of Aleppo, Aleppo, Syria; \\ ${ }^{3}$ Syrian Research Cancer Centre of the Syrian Society against Cancer, Aleppo, Syria; \\ ${ }^{4}$ Department of Oncology, McGill University, Montreal, Canada; \\ ${ }^{5}$ Department of Mechanical Engineering, Concordia University, Montreal, Canada.
}

Received 3 April 2011; revised 19 April 2011; accepted 10 May 2011.

\begin{abstract}
Lung cancer is the first common malignancy worldwide; in view of the limited success of available treatment modalities for this cancer, alternative and complementary strategies need to be developed. On the other hand, Teucrium polium (TP) is a medicinal plant that has been used for more than two thousand years for treating many diseases such as abdominal pain, indigestion and diabetes in the Middle East. However, the effect of TP plant extract on human non-small cell lung cancer (NSCLC) has not been investigated yet. In this study, we examined the effects of TP extract on cell proliferation, cell cycle progression and cell death in H322 and A549 lung cell lines. Our results show that TP plant extract inhibits cell proliferation and deregulates cell cycle progression. More importantly, TP plant extract causes a dramatic cell death in both cell lines in comparison with untreated cells. Our data suggest that this plant extract could have an important therapeutic role in the treatment of human NSCLC.
\end{abstract}

Keywords: Teucrium Polium Plant Extract; Lung Cancer; Cell Death

\section{INTRODUCTION}

Lung cancer remains the most common malignancy worldwide with approximately 1.3 million new cases and 300,000 deaths each year estimated by the World Health Organization. In view of the limited success of available treatment modalities for lung cancer, especially metastatic forms [1], alternative and complementary strategies need to be developed. Thus, several topical studies revealed that the epidermal growth factor-receptor (EGF-R), a member of the ErbB family of receptor tyrosine kinases, has been over-expressed and therefore identified as a therapeutic target for several human carcinomas including non-small cell lung cancer (NSCLC) [2-4]. Alternatively, we have reported that a ligandblocking monoclonal antibody $(\mathrm{mAb})$ against the EGF-R, LA1, inhibits cell motility of two human NSCLC cell lines, H322 and A549, which over-express EGF-R. This is accompanied by restoration of the E-cadherin/catenin complex which is an important regulator of cell invasion and metastasis [5-7]. While, EGFR-targeted therapies have been recently approved using small molecules that are tyrosine kinase inhibitors (TKI) such as erlotinib and gefitinib or monoclonal antibodies (cetuximab and panitumumab) which can block receptor dimerization and activation. However, the response rate to these current drugs is modest. Therefore, new strategies to treat human lung carcinomas are still major focus of investigations.

On the other hand, the medicinal use of plants dates back to ancient times. Teucrium polium (TP) is a plant that has been used for over two thousand years in traditional medicine $[8,9]$. This plant is widely distributed in the majority of the Middle East as well as Mediterranean countries. Earlier studies reported the presence of flavonoids, iridoids and hypoglycemic activity in $T P$ plants [10-12]. Traditionally $T P$ is used for its antispasmodic and hypoglycemic activities by the native inhabitants and is recommended by the herbalists $[13,14]$. Nevertheless, the effect of the TP plant extract on human lung cancer remains to be determined. Therefore, in this study, we examined the effects of $T P$ extract on selected parameters of human lung cancer cell lines, H322 and A549. 


\section{MATERIALS AND METHODS}

\subsection{Cell Culture}

The human lung cancer cell lines H322 and A549 were obtained from the American Type Culture Collection (ATCC). These cell lines were cultured in Dulbecco modified Eagle's medium (DMEM) with $5 \%$ fetal bovine serum (FBS) and incubated at $37^{\circ} \mathrm{C}$ in a $5 \% \mathrm{CO}_{2}$ atmosphere.

\subsection{Plant Material and Extract Preparation}

The aerial parts of Teucrium polium were collected from Al-Raka, Syria. The herbs were dried in the shade and stored in a dark container. Dry plant material was ground finely and the extract was prepared by boiling $1.5 \mathrm{~g}$ of plant material per $50 \mathrm{ml}$ of autoclaved water for $20 \mathrm{~min}$ in a covered beaker on a warming plate. The solution was then filtered using $0.45 \mu \mathrm{m}$ filter [15]. Dilutions of the extracts were prepared in cell culture medium and applied to the cultures.

\subsection{Cell Proliferation Assay}

Cells $\left(1 \times 10^{5} / \mathrm{ml}\right)$ were plated in 6-well dishes in their regular media (control cells) or containing 100, 150 and $200 \mu \mathrm{l} / \mathrm{ml}$ of TP plant extract. Cells from duplicate wells were collected by trypsinization, washed and counted every two days using trypan blue exclusion and hemocytometer. As control, we used another medicinal plant from Syria, Chamomilla chamomile which did not induce the same affect on cell proliferation and cell cycle progression in $\mathrm{H} 322$ and A549 cell lines.

\subsection{Cell Cycle Analysis}

H322 and A549 cells were treated with 100, 150 and $200 \mu \mathrm{l} / \mathrm{ml}$ of $T P$ plant extract for two days. Cells were harvested, washed and fixed and subsequently treated with $50 \mu \mathrm{g} / \mathrm{ml}$ RNase and stained with $50 \mu \mathrm{g} / \mathrm{ml}$

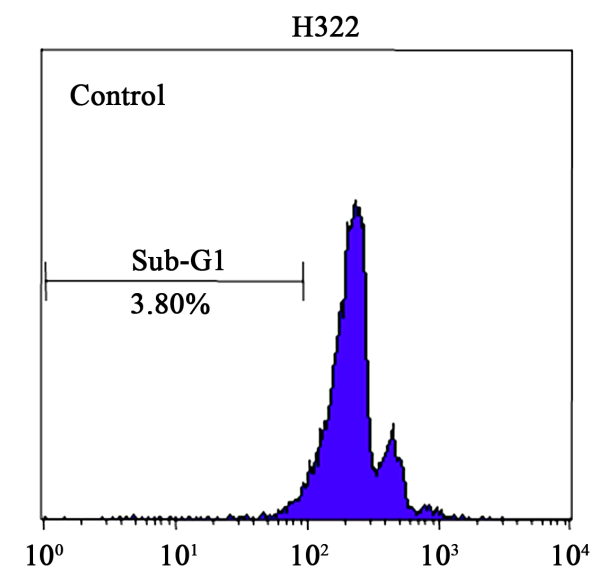

Copyright $\odot 2011$ SciRes. propidium iodide for $30 \mathrm{~min}$, then they were analyzed in a FACS-Calibur and data were evaluated with Cell Quest and ModFitLT v3.1 software.

\section{RESULTS \& DISCUSSION}

In order to explore the role of $T P$ plant extract as a potential treatment for human lung carcinomas, we examined the effect of the aqueous extract of $T P$, which is prepared as previously descried by Kandouz et al. [15], on cell proliferation, cell cycle progression and cell death in H322 and A549 human lung carcinoma cell lines. We found that treatment with TP plant extract inhibits cell proliferation, deregulates cell cycle progresssion, and induces significant cell death in these cell lines in comparison with untreated (control) cells (data not shown and Figure 1); it is clear that the treatment with 0, 100,150 and $200 \mu \mathrm{l} / \mathrm{ml}$ of $T P$ plant extract leads to a dose-dependent increase in cell death in H322 and A549 cell lines (Figure 1). Thus, this study clearly demonstrates that $T P$ plant extract provokes cell death in human NSCLC. While, it has been reported that the TP plant extract has antioxidant properties [16]; and the bioactive compounds contained flavonoids and neoclerodane diterpenoids [17,18]. Recently, Rajabalian [19], has revealed that combinations of $T P$ extract and anticancer drugs such as vincristine and/or doxorubicin induce a massive apoptosis compared to the effect of individual drugs in several human cancer cell lines such as MCF7, A431, SW480 Skmel-3 and EJ; moreover, he found that combination of those anticancer drugs with $T P$ plant extract reduce the cytotoxic effects of vincristine and vinblastine on human normal fibroblasts. Recently we demonstrated that the $T P$ plant extract inhibits cell proliferation of two human prostate cancer cell lines, PC3 and DU145 cells; however, this inhibition is accompanied by a small induction of cell death. On the other hand, we found that $T P$ extract induces differentiation to an epithelial phenotype "mesenchymal-epithelial

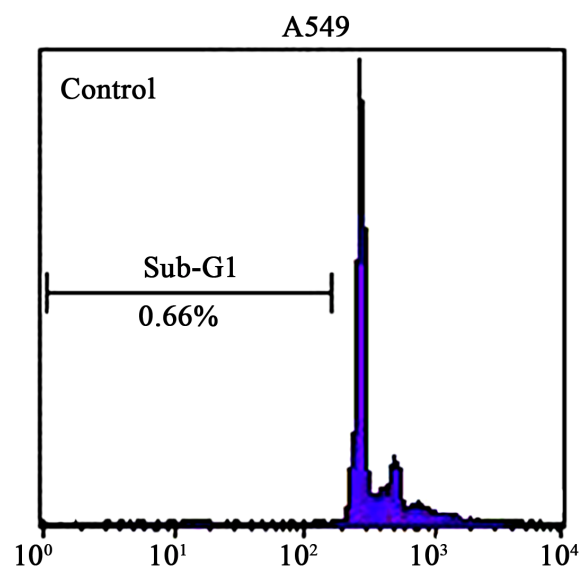



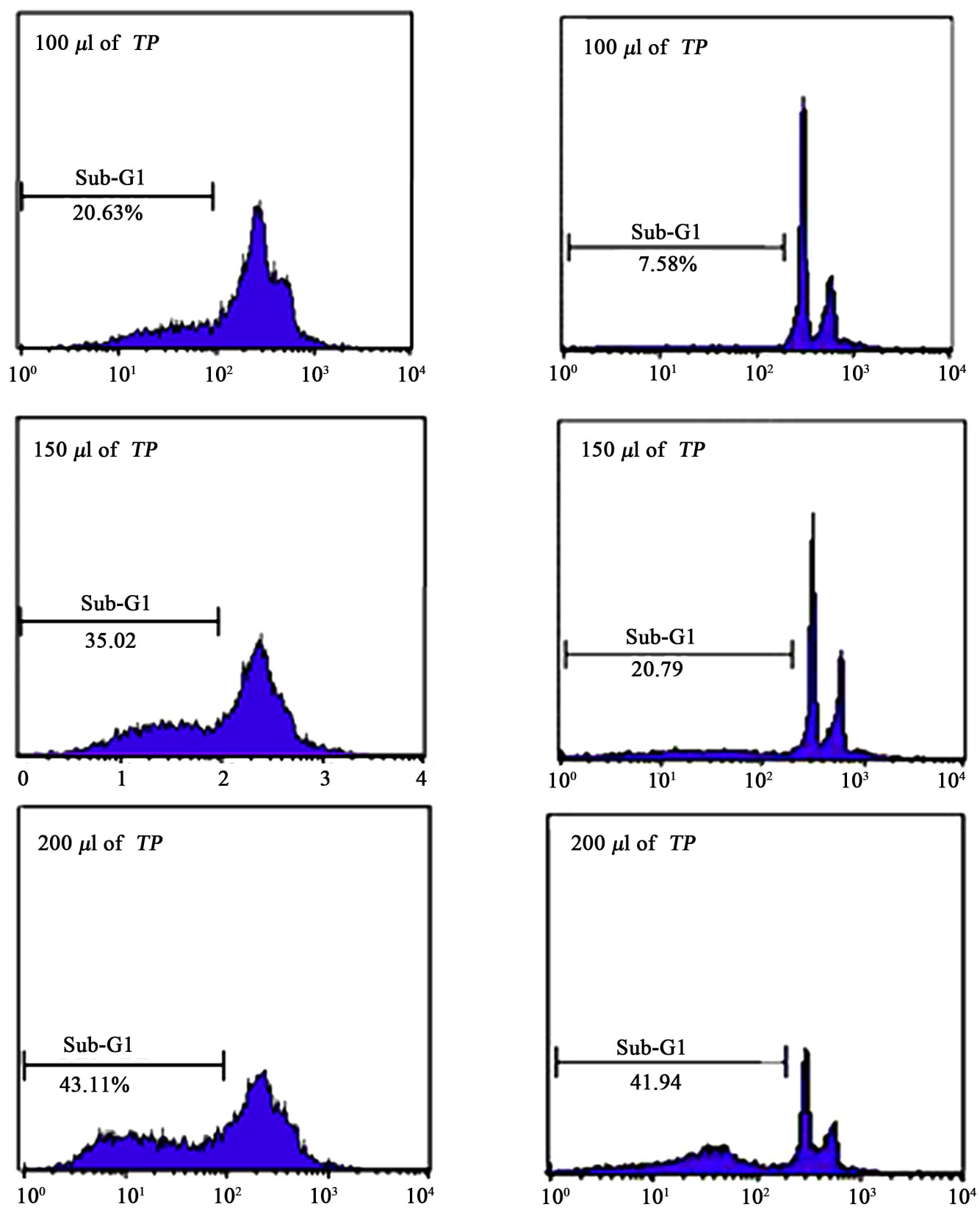

Figure 1. Teucrium polium (TP) plant extract induces a significant cell death (Sub-G1) in H322 and A549 human lung cancer cells. Propidium iodide staining shows a significant increase $(P<0.0001$ and $P<0.001)$ in the proportion of H322 and A549 cells, respectively, in the Sub-G1 phase of the cell cycle following $48 \mathrm{~h}$ of $T P$-treatment especially with $(200 \mu \mathrm{l} / \mathrm{ml})$ using flow cytometry analysis.

transition", which is an important event in cell invasion and metastasis, in human prostate cancer cell lines; thus $T P$ plant extract causes a dramatic decrease in cell invasion and motility of these cancer cells. These changes are accompanied by a re-localization of the expression patterns of E-cadherin and catenins. Moreover, we revealed that this plant extract inhibits the phosphorylation of $\beta$-catenin, via Src dephosphorylation, and consequently converts its role from a transcriptional regulator to a cell-cell adhesion molecule [15]. In parallel, it is well established that flavonoid compounds have anticancer property and can induce apoptosis through p53 and other regulators of cell apoptosis [20]. Meanwhile, flavonoids are present in the TP plant [10]; therefore, we believe that the cell death induced by $T P$ plant extract could be related to p53 activation as well as other regulators of cell death and apoptosis.

In conclusion, this is, to the best of our knowledge, the 
first study on the effect of $T P$ plant extract in human NSCLC cells. Moreover, this investigation is the first evidence demonstrating that $T P$ plant extract induces a significant cell death of human lung carcinoma cells. Therefore, we firmly believe that this investigation will have several clinical implications in the treatment of certain types of human carcinomas including lung cancer.

\section{ACKNOWLEDGEMENTS}

We are grateful to Mrs. A. Kassab and Dr. A. Yasmeen for critical reading of the manuscript. This work is supported by the Canadian Institutes for Health Research (CIHR) and the Syrian society against cancer.

\section{REFERENCES}

[1] Toh, C.K. (2009) The changing epidemiology of lung cancer. Methods in Molecular Biology, 472, 397-411. doi:10.1007/978-1-60327-492-0 19

[2] Al Moustafa, A.E., Alaoui-Jamali, M., Paterson, J. and O'Connor-McCourt, M. (1999) Expression of P185erbB-2, P160erbB-3, P180erbB-4, and heregulin alpha in human normal bronchial epithelial and lung cancer cell lines. Anticancer Research, 19, 481-486.

[3] Hirsch, F.R., Scagliotti, G.V., Langer, C.J., Varella-Garcia, M. and Franklin, W.A. (2003) Epidermal growth factor family of receptors in preneoplasia and lung cancer: perspectives for targeted therapies. Lung Cancer, 41, S29- S42. doi:10.1016/S0169-5002(03)00137-5

[4] Volante, M., Saviozzi, S., Rapa, I., Ceppi, P., Cappia, S., Calogero, R., Novello, S., Borasio, P., Papotti, M. and Scagliotti, G.V. (2007) Epidermal growth factor ligand /receptor loop and downstream signaling activation pattern in completely resected nonsmall cell lung cancer. Cancer, 110, 1321-1328. doi:10.1002/cncr.22903

[5] Al Moustafa, A.E., Yansouni, C., Alaoui-Jamali, M.A. and O'Connor-McCourt, M. (1999) Up-regulation of Ecadherin by an anti-epidermal growth factor receptor monoclonal antibody in lung cancer cell lines. Clinical Cancer Research, 5, 681-686.

[6] Al Moustafa, A.E., Yen, L., Benlimame, N. and AlaouiJamali, M.A. (2002) Regulation of E-cadherin/catenin complex patterns by epidermal growth factor receptor modulation in human lung cancer cells. Lung Cancer, 37, 49-56. doi:10.1016/S0169-5002(02)00025-9

[7] Yasmeen, A., Bismar, T.A. and Al Moustafa, A.E. (2006) ErbB receptors and epithelial-cadherin-catenin complex in human carcinomas. Future Oncology, 2, 765-781. doi:10.2217/14796694.2.6.765

[8] Said, O., Khalil, K., Fulder, S. and Azaizeh, H. (2002) Ethnopharmacological survey of medicinal herbs in Israel, the Golan Heights and the West Bank region. Journal of Ethnopharmacol, 83, 251-265. doi:10.1016/S0378-8741(02)00253-2
[9] Ljubuncic, P., Dakwar, S., Portnaya, I., Cogan, U., Azaizeh, H. and Bomzon, A. (2006) Aqueous Extracts of Teucrium polium possess remarkable antioxidant activity in vitro. Evidence-based Complementary and Alternative Medicine, 3, 329-338. doi:10.1093/ecam $/$ nel028

[10] Rizk, A.M., Hammouda, F.M., Rimpler, H. and Kamel, A. (1986) Iridoids and flavonoids of Teucrium polium herb1. Planta Medica, 52, 87-88. doi:10.1055/s-2007-969087

[11] Al-Hader, A.A., Hasan, Z.A. and Aqel, M.B. (1994) Hyperglycemic and insulin release inhibitory effects of Rosmarinus officinalis. Journal of Ethnopharmacol, 43, 217-221. doi:10.1016/0378-8741(94)90046-9

[12] Talpur, N., Echard, B., Ingram, C., Bagchi, D. and Preuss, H. (2005) Effects of a novel formulation of essential oils on glucose-insulin metabolism in diabetic and hypertensive rats: a pilot study. Diabetes, Obesity and Metabolism, 7, 193-199. doi:10.1111/j.1463-1326.2004.00386.x

[13] Ali-Shtayeh, M.S., Yaniv, Z. and Mahajna, J. (2000) Ethnobotanical survey in the Palestinian area: a classification of the healing potential of medicinal plants. Journal of Ethnopharmacol, 73, 221-232. doi:10.1016/S0378-8741(00)00316-0

[14] Abu-Irmaileh, B.E. and Afifi, F.U. (2003) Herbal medicine in Jordan with special emphasis on commonly used herbs. Journal of Ethnopharmacol, 89, 193-197. doi:10.1016/S0378-8741(03)00283-6

[15] Kandouz, M., Alachkar, A., Li, Z., Dekhil, H., Chehna, F., Amber, A. and Al Moustafa, A.E. (2010) Teucrium polium plant extract inhibits cell invasion and motility of human prostate cancer cells via the restoration of the E-cadherin/catenin complex. Journal of Ethnopharmacol, 129, 410-415. doi:10.1016/j.jep.2009.10.035

[16] Suboh, S.M., Bilto, Y.Y. and Aburjai, T.A. (2004) Protective effects of selected medicinal plants against protein degradation, lipid peroxidation and deformability loss of oxidatively stressed human erythrocytes. Phytotherapy Research, 18, 280-284. doi: $10.1002 /$ ptr. 1380

[17] Kadifkova P.T., Kulevanova, S. and Stefova, M. (2005) In vitro antioxidant activity of some Teucrium species (Lamiaceae). Acta Pharmaceutica, 55, 207-214.

[18] Piozzi, F., Bruno, M., Ciriminna, R., Fazio, C., Vassallo, N., Arnold, N.A., de la Torre, M.C. and Rodriguez, B. (1997) Putative hepatotoxic neoclerodane diterpenoids from Teucrium species. Planta Medica, 63, 483-484. doi:10.1055/s-2006-957744

[19] Rajabalian, S. (2008) Methanolic extract of Teucrium polium L. potentiates the cytotoxic and apoptotic effects of anticancer drugs of vincristine, vinblastine and doxorubicin against a panel of cancerous cell lines. Experimental Oncology, 30, 133-138.

[20] Lin, Y., Shi, R., Wang, X. and Shen, H.M. (2008) Luteolin, a flavonoid with potential for cancer prevention and therapy. Current Cancer Drug Targets, 8, 634-646. doi: $10.2174 / 156800908786241050$ 